\title{
OLDER HYPERTENSIVE PATIENTS' ADHERENCE TO HEALTHY LIFESTYLE BEHAVIORS
}

Marija Andjelkovic ${ }^{1,2}$, Marina Mitrovic ${ }^{2}$, Ivana Nikolic ${ }^{2}$, Danica Bacanin Jovanovic ${ }^{3}$, Ivanka Zelen², Milan Zaric ${ }^{2}$, Petar Canovic ${ }^{2}$, Aleksandra Kovacevic, Slobodan Jankovic ${ }^{4}$

${ }^{1}$ Department of Laboratory Diagnostics, Clinical Center Kragujevac, Kragujevac, Serbia

${ }^{2}$ Department of Biochemistry, Faculty of medical sciences, University of Kragujevac, Kragujevac, Serbia ${ }^{3}$ Health Care Center Kragujevac, Kragujevac

${ }^{4}$ Department of Pharmacology, Clinical Center Kragujevac, Faculty of medical sciences, University of Kragujevac, Kragujevac, Serbia

\section{PRIDRŽAVANJE STARIH HIPERTENZIVNIH PACIJENATA} ZDRAVIM ŽIVOTNIM NAVIIKAMA

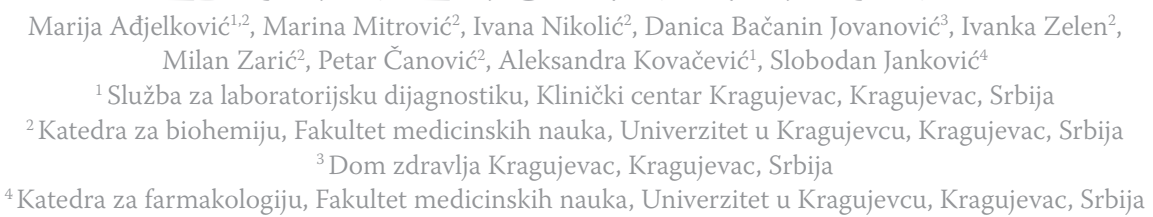

Received / Primljen: 04. 07. 2016.

Accepted / Prihvaćen: 22. 10. 2016.

\begin{abstract}
Non-pharmacological treatment including diet, body weight reduction, smoking cessation and physical activity, is very important part of hypertension treatment. The objective of this study was to investigate the adherence to healthy lifestyle behavior in the representative sample of the older hypertensive patients, and to investigate factors associated with adherence in the studied older population. The study was conducted on random sample of 362 long term hypertensive ( $>$ five years) patients older than 65 years of age, at Health Care Center of Kragujevac. Adherence was assessed using the structured questionnaire for the analysis of the implementation of both hypertension and diabetes guidelines in the primary care. Both bivariate and multivariate analyses were conducted. Nearly $35 \%$ of examined patients were highly adherent; they exercised regularly, avoided smoking for at least five years and consumed special healthy diet prescribed for hypertension. Another $35.6 \%$ of the cases reported exercising regularly, 39.5\% followed the recommended diet for the hypertension, while $23.4 \%$ of the patients have still consumed cigarettes. Multivariate logistic regression demonstrated that received counseling on healthy lifestyle behaviors by physicians and lack of education predicted high adherence to healthy lifestyle behavior. In order to improve adherence of elderly hypertensive patients to healthy lifestyle, strengthening patient-physician relationships through efforts to enhance communication may be a promising strategy to enhance patients' engagement in healthy lifestyle behaviors for hypertension. Such an improvement could be achieved through the education of both the physicians and patients.
\end{abstract}

Key words: hypertension, older patients, lifestyle adherence

\section{SAŽETAK}

Nefarmakološki tretman koji uključuje dijetu, smanjenje telesne mase, prestanak pušenja i fizičku aktivnost je veoma važan u lečenju hipertenzije. Cilj ovog istraživanja je bio ispitati na reprezentativnom uzorku starijih pacijenata obolelih od hipertenzije u kojoj meri se oni pridržavaju zdravih životnih navika kao i koji faktori utiču na to. Ispitivanu grupu je činio uzorak od 362 slučajno odabrana pacijenta Doma zdravlja Kragujevac starijih od 65 godina koji su imali hipertenziju duže od pet godina. Komplijansa je procenjivana pomoću strukturiranog upitnika za analizu primene vodiča za hipertenziju i dijabetes u primarnoj zdravstvenoj zaštiti. Za obradu podataka korišćene su bivarijantna i multivarijantna analiza. Približno 35\% ispitanih pacijenata je pokazalo dobru komplijansu: redovno je vežbalo, nisu bili pušači najmanje pet godina i pridržavali su se dijete za hipertenziju. $35,6 \%$ pacijenata je redovno vežbalo, 39,5\% se pridržavalo dijete za hipertenzivne pacijente, dok je 23,4\% pacijenata koristilo cigarete. Multivarijantnom logističkom regresijom je pokazano da su savetovanje o zdravim životnim navikama od strane lekara i niži obrazovni status pacijenata prediktori dobre komplijanse kada su u pitanju zdrave životne navike. U cilju većeg pridržavanja zdravim životnim navikama starijih pacijenata obolelih od hipertenzije potrebno je jačanje odnosa pacijent-lekar putem napora da se unapredi komunikacija što može biti strategija koja dovodi do većeg angažovanja pacijenata na polju zdravih životnih navika Taj napredak bi mogao biti postignut edukovanjem kako lekara tako i pacijenata.

Ključne reči: hipertenzija, stariji pacijenti, pridržavanje zdravim životnim navikama 


\section{INTRODUCTION}

Hypertension is one of the most common illnesses among adults. The national health survey conducted by Institute of Public Health of Serbia „Dr Milan Jovanovic Batut", in $2006^{\text {th }}$, estimated that $77.2 \%$ of population aged over 65 years and $75.7 \%$ over 75 years of age had increased systolic blood pressure (1). The nonpharmacological treatment such as life style modifications that include diet, body weight reduction, smoking cessation and regular physical activity in combination with medical therapy are very effective measures for optimum treatment of hypertension. According to the latest Guidelines for the management of arterial hypertension of the European Society of Hypertension (ESH) and of the European Society of Cardiology (ESC) lifestyle behaviors that reduce blood pressure are: salt restriction, high consumption of fruits and vegetables, low-fat diet, regular physical exercise and weight reduction (2). Moreover, according to behavioral model, even the most effective therapy will not ensure acceptable results of treatment if a patient is not motivated to adopt physician-recommended healthy lifestyle modifications and medication adherence for hypertension control (3). However, patients' compliance with both part of the treatment is usually low, and that could be a main reason for only one third of patients having their blood pressure controlled (4).

The elderly patients with hypertension are highly specific in regard to their behavior and adherence to antihypertensive treatment. A far more disturbing finding is that the control of hypertension and compliance to the healthy lifestyles in older patients is far worse than that achieved in the hypertensive patients of other age groups. Elderly hypertensive patients require better life quality control even more than the other patients since they retained harmful lifestyles behaviors such as physical inactivity and non-antihypertensive diet, while smoking cessation was accepted (5). On the other hand, the age is not significant predictor of adherence to physical exercise, while the exercise duration correlates well with the percentage of adherence (6). In addition, self-care ability of hypertensive patients is important factor in the control of hypertension that is most often impaired in the elderly (7). The adequate knowledge of a healthy life styles and proper skills of patients are also necessary for positive influence of the adherence to good quality of life $(8,9)$. However, the other potential factors that may influence the adherence to healthy lifestyle in elderly have not yet been investigated.

The aim of this study was to investigate the adherence to healthy life style behaviors in older hypertensive patients and the factors associated with adherence, such as those that are patient's related including demographic factors, general behavior and beliefs and physician's related including counseling by physicians about healthy lifestyle and self - management of hypertension.

\section{PATIENTS AND METHODS}

The study was conducted at Health Care Center of Kragujevac, in November 2015. year and it included only the urban population of hypertensive patients. The study was approved by the Ethics Committee of Health Center Kragujevac and was done and in accordance with the Helsinki Declaration.

The inclusion criteria of patients were as followed: above 65 years of age and diagnosed with hypertension 5 years ago or more, while the exclusion criteria were: the patient's refusing to participate in the study, the patient's acute condition visiting the Health Care Center at the moment of the investigation performed and the patient's dementia (as diagnosed by psychiatrist or neurologist).

Those patients that fulfilled the inclusion criteria were enlisted with for the encounter with the physician every day with the assigned number starting from number one to the maximum count of patients for that day. Then, applying the random number generation function from Microsoft Excel computer program, a sample of 1 out of 10 of the number of patients for that day was randomly selected for the participation in the study. These patients were provided with the structured questionnaire that included questions about their sociodemographic and medical characteristics, lifestyle behaviors, knowledge and beliefs about hypertension and its management, and about received counseling regarding their lifestyle and self-management (with questions shown in Table 1-3). The same questionnaire was already used in previous study regarding the analysis of the implementation of the hypertension and diabetes guidelines in the primary care (10). For the illiterate patients, the questionnaire was filled by an investigator, on the basis of oral responses received by the patients.

The study's outcome variable was the patient's reported adherence to the healthy lifestyle behavior. The patients were asked about implementing the following elements of the healthy lifestyle: the hypertension diet (limited salt consumption, calorie limitation), the physical activity (at least half an hour daily exercise), and the smoking cessation (at least for the past 5 years if they were previously smokers). The patients who reported the adherence to all of the elements of the healthy lifestyle were designated as the "highly adherent", and the rest of the patients were designated as the "low adherent".

The independent variables of the study were: the demographic characteristics (age, gender, education, family status), the body mass index, the blood pressure level-measured by a health worker during the actual visit, the blood pressure control (i.e. for the question 'is your BP controlled' from the questionnaire -the 'yes' response was assigned to the patients whose BP was mostly below $140 \mathrm{mmHg}$ for systolic and $90 \mathrm{mmHg}$ for diastolic, and never exceeded BP of 160/95 mmHg; the response 'sometimes' was assigned to those with BP that exceeded 160/95 mmHg, 1-2 times monthly, and the response 'no' was assigned to the patients with BP higher than 140/90 $\mathrm{mmHg}$ generally), regularity 
Table 1. Sociodemographic and medical characteristics of patients

\begin{tabular}{|c|c|}
\hline \multirow[t]{2}{*}{ characteristic } & number of patients \\
\hline & $362(100)^{*}$ \\
\hline \multicolumn{2}{|l|}{ Gender } \\
\hline Male & $156(43)$ \\
\hline Female & $206(57)$ \\
\hline \multicolumn{2}{|l|}{ Family status } \\
\hline Married/living with partner & $231(63.7)$ \\
\hline Divorced/separated & $6(1.4)$ \\
\hline Widowed & $120(33.2)$ \\
\hline Single & $5(1.7)$ \\
\hline \multicolumn{2}{|l|}{ Education (years of education) } \\
\hline without education & $34(9.4)$ \\
\hline up to 4 yrs & $43(11.9)$ \\
\hline $5-8$ yrs & $112(30.9)$ \\
\hline $9-12$ yrs & $130(35.9)$ \\
\hline $13+$ & $43(11.9)$ \\
\hline \multicolumn{2}{|l|}{ BMI } \\
\hline Normal & $143(39.5)$ \\
\hline Overweight & $160(44.2)$ \\
\hline Obese & $59(16.3)$ \\
\hline \multicolumn{2}{|c|}{$\begin{array}{l}\text { Systolic and diastolic blood pressure } \\
\text { when last checked }\end{array}$} \\
\hline Healthy, below 140/90 & $178(49.2)$ \\
\hline $140 / 90-159 / 99$ & $131(36.1)$ \\
\hline $160 / 99-179 / 109$ & $30(8.2)$ \\
\hline Over $180 / 110$ & $13(3.5)$ \\
\hline \multicolumn{2}{|c|}{ Is your blood pressure controled? } \\
\hline Yes & $208(57.5)$ \\
\hline Sometimes & $75(20.7)$ \\
\hline No & $79(21.8)$ \\
\hline
\end{tabular}

* the number in parenthesis is the percentage of respodents with valid answer for each field

of medication (whether the patient take all the prescribed medications regularly), the received counseling regarding healthy lifestyle and self-management (the content of this variable is shown in Table 3), the knowledge about hypertension, beliefs about hypertension management, and perceived responsibility for the hypertension management (the contents of the last three variables are shown in Table 2 ). If the patient answered yes on all questions regarding lifestyle and self-management counseling by physician, than patient's received counseling about lifestyle and selfcare management was mark as high. The knowledge of those who answered correctly on all the statements about hypertension (section Knowledge in Table 2) was marked as high and the others' as low. If all patient's beliefs about the hypertension management were constructive (section Beliefs in Table 2) than those beliefs were marked as high, and if that was not the case - beliefs were marked as low. The
Table 2. Patients reported health behaviors, knowledge and beliefs about hypertension and its management



Do not know 18.0)

A hypertension patient has to be treated constantly, whether or not his/her health improves

Agree $223 \quad$ (61.6)

Do not entirely agree

Disagree $\quad 64 \quad$ (17.7)

Do not know $\quad 53 \quad$ (14.6)

I believe that is possible to control my blood pressure

Agree $\quad 291 \quad$ (80.4)

Do not entirely agree 31

Disagree 12

Do not know

Who is responsible for ensuring your blood pressure is

balanced?

Full/main responsibility is with the doctor and/or nurse 121 Full/main responsibility is with the patient $\quad 241$

* the number in parenthesis is the percentage of respodents with valid answer for each field 
Table 3. Patients' reports on received counseling regarding lifestyle and self-management

\begin{tabular}{lc}
\hline Counseling by medical staff & number of patients \\
\hline Lifestyle counseling & \\
\hline Current physician recommended physical activity & \\
Yes & 105
\end{tabular}

Current physician discussed smoking cessation (current smokers only) Yes 35

Current physician discussed the need for suitable diet-what you may and may not eat

\begin{tabular}{lcl} 
Yes & 198 & $(54.7)$ \\
\hline Current physician discussed your desirable weight & \\
Yes & 173
\end{tabular}

Self-management counseling

Current physician explained the risks and complications of high blood pressure

Yes $183 \quad$ (50.5)

Current physician explained how to measure blood pressure by yourself

Yes $177 \quad$ (48.9)

Current physician explained about signs for deterioration

Yes 104

* the number in parenthesis is the percentage of respondents with valid answer for each field

normal range for BMI was 18.50 - 24.99, for the overweight $25.00-29.99$ and for the obese BMI were 30 or more.

The raw data were processed by the descriptive statistics, with the percentages of patients having certain value of the variables. The influence of the following variables of the study including gender, education, family status, perceived responsibility on hypertension management, beliefs about hypertension management, knowledge about hypertension and received counseling by medical team on the study outcome (adherence or non-adherence) was tested by the univariate logistic regression, and the crude odds ratios were obtained. Furthermore, all the variables tested with univariate analysis were entered into the multivariate logistic regression, and the adjusted odds ratios were obtained.
The level of significance for the acceptance of a null hypothesis was $\mathrm{p}<0.05$. All calculations were performed by the statistical software SPSS Version 18.0 (SPSS, Chicago, IL).

\section{RESULTS}

This study involved the random sample of 362 outpatients of a total cohort of 3470 elderly hypertensive patients. Twenty two patients refused to participate in the study. The mean age of the studied population was 71.9 years. Demographic characteristics of the study group are presented in Table 1. The facts related to patients' general lifestyle behavior, their knowledge about hypertension and beliefs about hypertension and its management are summarized in Table 2. The information concerning the received counseling about lifestyle and self-management by medical staff is shown in Table 3.

The variables such as lack of education and high score in reported counseling by the primary care physician on healthy lifestyle behavior predicted high scores of adherence to healthy lifestyle behavior (odds ratio 0.31, $\mathrm{p}<0.05$; $29.58, \mathrm{p}<0.05$, respectively). The other variables (gender, family status, perceived responsibility on hypertension management, and beliefs and knowledge about hypertension) did not have statistically significant impact on the adherence to healthy lifestyle (Table 4).

\section{DISCUSSION}

The results of our study confirmed the well-known fact that adherence of hypertensive patients to healthy lifestyle in is far from optimal (10). According to the data obtained by "The Seventh Report of the Joint National Committee on Prevention, Detection, Evaluation, and Treatment of High Blood Pressure" suggesting that only one third of hypertensive patients had well controlled blood pressure (5), at least a part of this problem could have been assigned to the low adherence to healthy lifestyle. Study conducted in Poland also proved that implementation of non-pharmacological treatment among hypertensive patients is at very

Table 4. Multivariate logistic regression: predictors of healthy lifestyle behavior

\begin{tabular}{|c|c|c|c|c|}
\hline & OR(crude) & CI $95 \%$ & OR adjusted & CI $95 \%$ \\
\hline Gender (male) & $0.58^{\prime \prime}$ & $0.37-0.90$ & 0.62 & $0.35-1.08$ \\
\hline Education (up to 8 years) & 1.349 & $0.87-2.08$ & $0.23 \%$ & $0.10-0.52$ \\
\hline Family status (married) & 0.97 & $0.62-1.53$ & 0.57 & $0.31-1.04$ \\
\hline Perceived responsibility (of medical team) & 0.71 & $0.44-1.13$ & 0.73 & $0.38-1.42$ \\
\hline Constructive beliefs about HTA (high) & $2.38 *$ & $1.34-4.22$ & 1.70 & $0.82-3.50$ \\
\hline Knowledge about HTA (high) & 1.22 & $0.67-2.20$ & 1.09 & $0.46-2.57$ \\
\hline Counseling (high) & $16.74^{*}$ & $9.64-29.01$ & $34.89^{*}$ & $16.06-75.82$ \\
\hline
\end{tabular}

$\mathrm{p}<0.05^{*}$

Hosmer and Lemshow test chi-square 2.92, $\mathrm{p}=0.94$ 
low level (11). Research on Korean hypertensive patients demonstrated that awareness of hypertension is increasing, but that did not lead to better adherence to healthy lifestyle (12).

Recent study showed that the intensive antihypertensive medical treatment combined with the lifestyle modification led to the better blood pressure control of hypertensive patients including the elderly (10). Apart from the factors linked to the patient itself that may influence adherence to either medication or healthy lifestyle (11) including depression, low social support and low quality of life, knowledge, beliefs and attitudes towards the hypertension, the patients counseling by their physicians also plays a key role in managing the hypertension. The results of our study demonstrated that only a third to no less than a half of hypertensive patients has been advised by their physician about the appropriate diet, physical activity and smoking cessation that were an obligatory part of a treatment. In addition, the counseling by the other health workers including pharmacists also plays an important role in medical adherence as well as in the adherence to lifestyle behavior $(12,13)$. Among the reasons for the low counseling rates by physicians could be assigned to their poor and/or inadequate knowledge regarding the hypertension and hypertension guidelines (14) and the short period of time allowed for the physician-patient encounter since the proper physicians counseling required more time (15, 16). Therefore, in order to improve their own counseling skills, the physicians need to be properly trained and to be more persistent and convincing in advising the hypertensive patients about the necessity of a lifestyle modification, since only a few hypertensive patients remembered being advised (17). Concerning the older hypertensive patients, there is the clinical inertia among the physicians which contributes to the inappropriate treatment of the elderly (18). In addition, the self-care ability which is more often reduced in some of the older patients impairs their compliance with the healthy lifestyle behavior, and makes their blood pressure being harder to control (6).

The older patients are generally less educated compared to the rest of the population, and therefore with lower health literacy. It has already been shown that the less educated patients were less aware of the effects of a lifestyle on health (19). Such patients have reduced ability to remember instructions received from the physician and also difficulty to recall information (20). The health care workers, both physicians and nurses should try to communicate more effectively with the patients using simple language and providing them with the information that would be understood by everyone around them. However, paradoxically, in our study the less educated elderly patients were more adherent to the healthy lifestyle than those with more education suggesting that the one of the reasons for the better adherence could be a higher submissiveness of less educated patients to the "orders" received from the physicians in a country with the authoritarian social structure $(21,22)$.
Considering that the received lifestyle counseling could be a good predictor of a healthy lifestyle behavior that was demonstrated in our and previous study (9), it could be concluded that the improving the communication skills between the physician and the patients is required to achieve the improvement in patient's adherence to the recommended lifestyle as well as to the prescribed medication.

It is important to note that this study was limited by several factors. Firstly, it was based on the patients selfreport about their lifestyle behavior and received counseling by physician; therefore the patient's tendency to be "socially desirable" could be one of the reasons for the incorrect (untruthful) answers on some of the questions. On the other hand, only the patients are able to provide the information regarding their lifestyle behaviors and physician's lifestyle counseling. Secondly, making the conclusion about the cause and the effects is impossible due to the cross-sectional nature of the study design. Our results could only reveal the possible relationship between the lifestyle behaviors and the independent variables in the multivariate regression model. In addition, another limitation factor of this study is the fact that the depression was not considered as a possible factor affecting the adherence to the patient's life-style modification.

\section{CONCLUSIONS}

Our study showed that counseling of the older hypertensive patients about a healthy lifestyle and self-care by their physician helped them modifying and keeping a healthy lifestyle. Furthermore, this study demonstrated that the counseling rates by physicians were low, suggesting the requirements of the improvement of the communication skills between patients and physicians. Following the appropriate communication training skills, the physicians would be able to counsel their patients more effectively and their efforts would result in the improvement of patients' adherence to healthy lifestyle. Moreover, it is also very important to involve patient's relatives in his or her everyday activities, especially for the patients who suffer from dementia and depression since they require the everyday family support regarding taking their medication, proper diet and physical exercise. Last, but not the least, the role of the nursesis substantial through the different supporting programs such as patients' clubs. Local media, in cooperation with medical authorities, could also take responsibility for the education of the patients and contribute to their healthy lifestyle.

\section{ACKNOWLEDGEMENTS}

The authors wish to thank to Dr. Jelena Obradovic and Dr. Snezana Djordjevic from Kragujevac, Serbia, who kindly helped with recruiting patients and other fellow GPs. 


\section{REFERENCES}

1. Ministry of Health - Republic of Serbia. National Health Survey Serbia 2006, Key Findings. Available at http://www.batut.org.rs/download/publikacije/National\%20Health\%20Survey\%20Serbia\%202006.pdf. Accessed on 10 Sep 2014.

2. $2013 \mathrm{ESH} / \mathrm{ESC}$ Guidelines for the management of arterial hypertension. European Heart Journal 2013; 34: 2159-2219.

3. Barrier PA, Li JT, Jensen NM. Two words to improve physician-patient communication: what else? Mayo Clin Proc 2003; 78(2): 211-214.

4. Chobanin A, Bakris G, Black H. The National High Blood Pressure Education Program Coordinating Comitee, The seventh report of the Joint National Comitee on Prevention, Detection, Evaluation, and Treatment of High Blood Pressure. JAMA 2003; 289: 2560-2572.

5. Neutel CI, Campbell NR, Canadian Hypertension Society. Changes in lifestyle after hypertension diagnosis in Canada. Can J Cardiol 2008; 24(3): 199-204.

6. Visek AJ, Olson EA, DiPietro L. Factors predicting adherence to 9 months of supervised excercisein healthy older women. J Phys Act Health 2011; 8(1): 104-110.

7. Leyva-Jiménez R, Venegas-Escobedo OE, Medel-Delgado AG. Self-care ability in the hypertensive patient control. Rev Invest Clin 2011; 63(4): 376-381.

8. Kearney MH, Rosal MC, Ockene JK, Churchill LC. Influences on older women's adherence to a low-fat diet in the Women's Health Initiative. Psychosom Med 2002; 64(3): 450-457.

9. Eshah NF. Predischarge education improves adherence to a healthy lifestyle among Jordanian patients with acute coronary syndrome. Nurs Health Sci 2013; 15(3): 273-279.

10. Heymann AD, Gross R, Tabenkin H, Porter B, Porath A. Factors associated with hypertensive patients' compliance with recommended lifestyle behaviors. Isr Med Assoc J 2011; 13(9): 553-557.

11. Jarosz M, Wolańska D, Stolińska H, Respondek W, Kłosiewicz-Latoszek L. Nutrition and lifestyle in patients pharmacologically treated due to hypertensionally treated due to hypertension. Cardiol J. 2016;. doi: 10.5603/CJ.a2016.0049.

12. Park K, Cho S, Bower JK. Changes in Adherence to Non-Pharmacological Guidelines for Hypertension. PLoS One. 2016; 11(8):e0161712.
13. Ohta Y, Tsuchihashi T, Kiyohara K, Oniki H. Trend of blood pressure control status in hypertensive outpatients: with special reference to elderly hypertensives. Clin Exp Hypertens 2012; 34(4): 258-263.

14. Holt EW, Muntner P, Joyce C, Morisky DE, Webber LS, Krousel-Wood M. Life events, coping, and antihypertensive medication adherence among older adults: the cohort study of medication adherence among older adults. Am J Epidemiol 2012; 176 Suppl 7: S64-71.

15. Ramanath K, Balaji D, Nagakishore C, Kumar SM, Bhanuprakash M. A study on impact of clinical pharmacist interventions on medication adherence and quality of life in rural hypertensive patients. J Young Pharm 2012; 4(2): 95-100.

16. Hroscikoski MC, Solberg LI, Sperl-Hillen JM, Harper PG, McGrail MP, Crabtree BF. Challenges of change: a qualitative study of chronic care model implementation. Ann Fam Med 2006; 4(4): 317-326.

17. Parker A, Nagar B, Thomas G, Badri M, Ntusi NB. Health practitioners' state of knowledge and challenges to effective management of hypertension at primary level. Cardiovasc J Afr 2011; 22(4): 186-190.

18. Chen LM, Farwell WR, Jha AK. Primary care visit duration and quality: does good care take longer?. Arch Intern Med 2009; 169(20): 1866-1872.

19. Abacı A. Management of cardiovascular risk factors for primary prevention: evaluation of Turkey results of the EURIKA study. Turk Kardiyol Dern Ars 2012; 40(2): 135-142.

20. Petrella RJ, Campbell NR. Awareness and misconception of hypertension in Canada: Results of a national survey. Can J Cardiol 2005; 21: 589-593.

21. Black HR. Management of older hypertensive patients: is there a difference in approach? J Clin Hypertens (Greenwich) 2003; 5(6 Suppl 4): 11-16.

22. Olszanecka-Glinianowicz M, Chudek J. The level of health education in the Polish population. Ann Agric Environ Med 2013; 20(3): 559-565.

23. McCarthy DM, Waite KR, Curtis LM, Engel KG, Baker DW, Wolf MS. What did the doctor say? Health literacy and recall of medical instructions. Med Care 2012; 50(4): 277-282.

24. Lukoschek P. African Americans' beliefs and attitudes regarding hypertensionand its treatment: a qualitative study. J Health Care Poor Underserved 2003; 14(4): 566-587.

25. Roehr B. Old authoritarian patterns of doctors' behaviour are still alive and well in California, study shows. BMJ 2012; 344: e3408. 